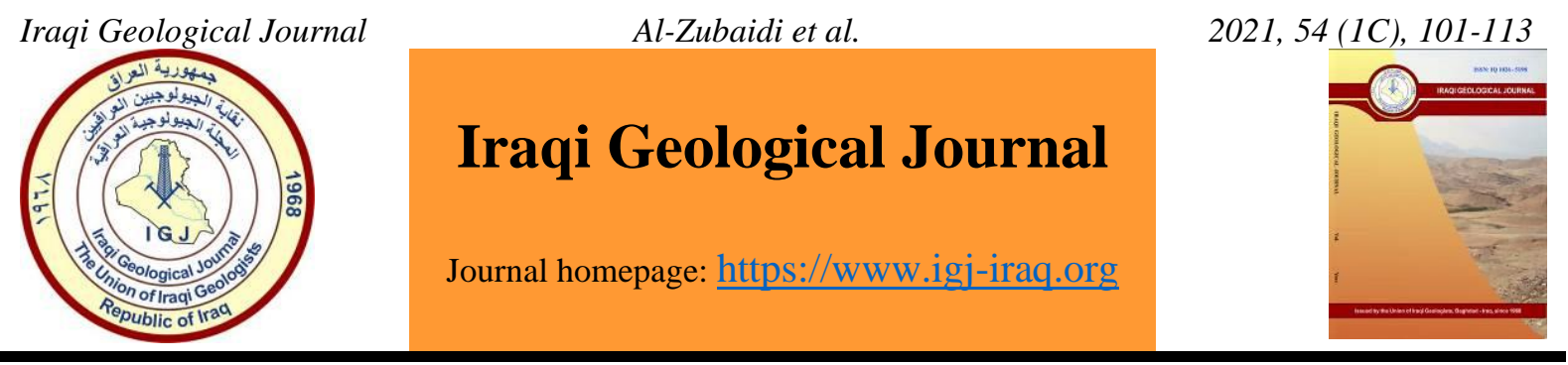

\title{
Mineralogy and Chemical Composition of Basalt Stone Tools in Some Iraqi Archaeological Sites
}

\author{
Aqeel A. Al-Zubaidi ${ }^{1, *}$, Hasan Kattoof Jasim² and Rami M. Idan' \\ ${ }^{1}$ Department of Geophysics, Al- Karkh University of Science, Baghdad, Iraq. \\ ${ }^{2}$ Department of Geology, University of Baghdad, Baghdad, Iraq. \\ *Correspondence: Aqeel.zubaidi.az@gmail.com
}

Received:14 November 2020; Accepted: 11 January 2021; Published :31 March 2021

\begin{abstract}
Basalt stone tools were collected from some Iraqi Archaeological Sites. Twenty-one samples were studied petrographically, mineralogically, and chemical composition. Five samples were from the Gaara Depression north of Rutba town, seven samples from Tarmiya, north Baghdad, seven samples from Dalmij site, east of Diwaniya city, and two samples from Jordan, which were used for comparison. The studied samples were classified into three groups, according to their mineralogy and texture: Group A: Vesicular Basalt, Group B: Dolerite, and Group $\mathrm{C}$ : Olivine Basalt. These stones most probably were used as a hand axe, grinder, hammer, and other uses, as well as for buildings, like those used in Qasar Al- Azraq and Umm Al- Jamal archaeological sites in Jordan. These basalt rocks most probably were transported by an ancient man from Harrat Al-Sham, which extends through Syria-Jordan-Saudi Arabia, or from NE Syria through a trade route that connected between source areas and the studied archaeological sites in Iraq.
\end{abstract}

Keywords: Vesicular; Olivine basalt; Dolerite; Harrat al-Sham; Trade route

\section{Introduction}

Basalt is a hard, dense volcanic igneous rock that occurs in many countries across the world (Al-Baijat, 2008). In the Middle East, basalt is especially exposed in the northeastern part of Iraq near the Iraq-ran border, which had been related to Alpine porphyritic glassy basalt; and in the Penjween Subzone which had been related to the Lower Cretaceous volcanicity, which contains spilitic basalt, metabasalt, spilites and basalt. The Shalair zone contains alkali olivine basalt, high aluminum basalt, basaltic andesites (Buday and Jassim, 1987). In Syria-JordanSaudi Arabia within Harat Al-Sham basalt (Ibrahim, 1993; Feduik and Al- Fugha, 1999; Aboud, 1999). In northeast Syria, the exposed basalt is of alkali olivine basalt, olivine phenocrysts and microphenocrysts have altered to Idengsite (Turkmani and Al- Shara, 2009). In Northeast Iran, the exposures are of basaltic andesite, trachyte andesite basalt, trachyte basalt, normal basalt, olivine basalt, and dolerite (Tehran, et al., 2010). The Central Iranian area includes basaltic andesite, andesite to trachyte andesite, quartz andesite, rhyolite rhyo-dacite and dacite

DOI: 10.46717/igj.54.1C.8Ms-2021-03-28 
(Chatroodi, et. Al., 2010). In addition to NE Turkey, there are basalt, trachybasalt, basaltic trachyandesite, trychite, andesite, basanite and tephrite (Yucel et al., 2014a). Ancient people have extensively used these types of basalt to manufacture grain grinder at some sites in northern Syria, and used for building at Umm Al-Jamal Nabatian city (about one century B.C.), which is located about $86 \mathrm{~km}$ north of Amman City. The mentioned city is located in a semiarid region; it is built entirely from basalt (De Vries, 1979). Basalt was also used as stone tools at some Iraqi archaeological sites (Braidwood and Howe, 1972; Al-Ani, 1986). This study aims to identify the petrography, texture, chemical compositions and trade routes of the basalt stone tools collected from some Iraqi archaeological sites.

\section{Materials and Method}

Twenty-one samples of basalt stone tools were collected. Nineteen from Iraqi archaeological sites (Map 1) and two samples from Jordan, near Azraq city (Table 1). The studied basalt stone tools samples were collected from four localities, three of them from Iraqi archaeological sites: The Ga'ara Depression (north of Rutba Town), Tarmiya site (north of Baghdad) and Dalmaj site (east of Diwaniya Town), as well as from Azraq city, Jordan (Fig. 1).

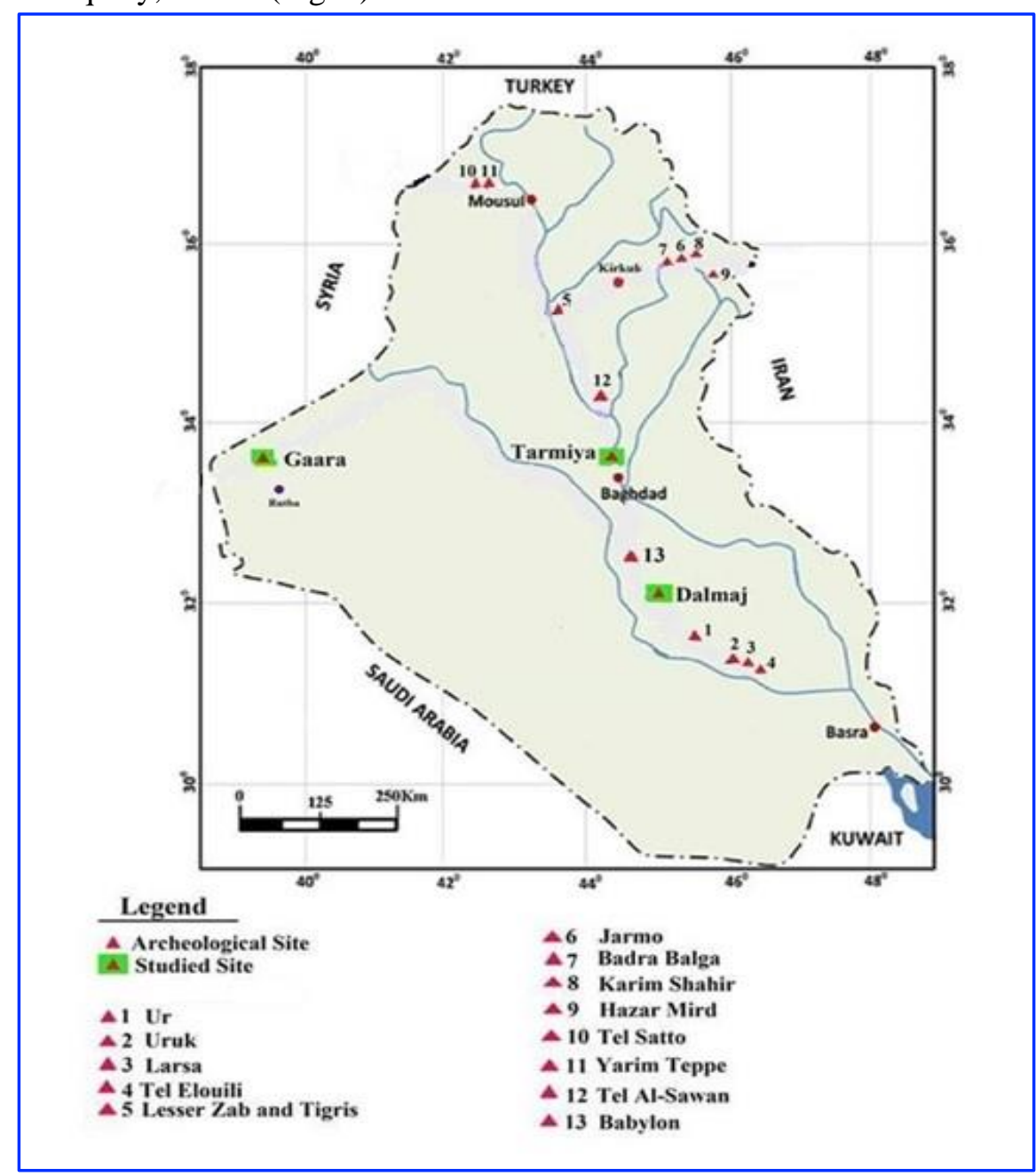

Fig. 1. Location map of the studied areas 
Table 1. Numbers and locality of the collected samples

\begin{tabular}{lcccc}
\hline Samples locality & $\begin{array}{c}\text { Dalmaj, } \\
\text { East Diwaniya }\end{array}$ & $\begin{array}{c}\text { Ga'ara, } \\
\text { North Rutba }\end{array}$ & $\begin{array}{c}\text { Tarmiya, } \\
\text { North Baghdad }\end{array}$ & Azraq Town, Jordan \\
\hline & D.1 & G.1 & T.1 & J.1 \\
D.2 & G.2 & G.3 & J.2 & \\
Sample No. & D.3 & G.4 & T.4 & \\
& D.4 & G.5 & T.5 & \\
& D.5 & & T.6 & \\
\hline
\end{tabular}

The study method includes seven steps:

- Basalt stone tools' samples collection from four sites.

- Description of the collected samples as a hand specimen.

- 3Thinned section study of 21 samples by polarized microscope to indicate the petrography of the studied samples.

- Chemical analysis (FRD) of four samples to determine the type of the studied rocks.

- Petrographic study of twenty-one representative samples of basalt stone tools was carried out by using a point counter mechanical stage as suggested by Chayes (1949). Five hundred counts per slide were preformed covering five major components: plagioclase feldspar, olivine, pyroxene, glass and magnetite.

- Field trip to Azraq Palace in Jordan for collecting samples.

- Literature survey on Umm Al-Jimal ancient city in Jordan.

\section{Results and Discussion}

\subsection{Provence of Basalt Stone Tools}

Basaltic igneous rocks are exposed in some countries at the Middle East, such as: northeast Iraq near Iraq- Iran border (Buday and Jassim, 1987), but this type of basalt is composed of pillow lava, which is not hard, in Syria- Jordan- Saudi Arabia within Harat Al-Sham (Aboud, 1999), northeast Syria (Turkmani and Al-Shara, 2009), northeast and central Iran (Tehran et al. 2010; Chatroodi, et Al. 2010). The nearest source area of basalt to Iraqi archaeological sites are Harat Al-Sham basalt in Jordan was used for building and stone tools in Umm Al-Jamal ancient town and Qasar Azraq; and also used for grinder manufacturing in northeast Syria. The outcrops of basalt at northeast Iraq may be near the archaeological sites, but they are composed of pillow lava which is not hard enough to be used as stone tools.

\subsection{Distribution of Basalt Stone Tools in Iraqi Archeological Sites}

The basalt stone tools were found at some archaeological sites in Iraq; such as in current study: Ga'ara Depression, Tarmiya, Dalmaj, and in some Iraqi archaeological sites such as: Yaram Tappa, Tel Sattoo, Tel Al-Sawan, Jarmo, Badra Balga, Karim Shahir, Hazar Mird, and others (Braidwood and Howe, 1972; Al-Ani, 1986). Moreover, in some Jordanian archaeological sites such as Umm Al-Jamal (De Vries, 1979), Qasar al-Azraq and others.

\subsection{Hand Specimen's Description}

The collected twenty-one stone tools' samples were visually described in the field. The description included color and textural properties. The color of basalt usually ranges from grey to black, but the weathering process has changed the color to the rusty color due to oxidation of mafic minerals. The colors of the studied stone tools' samples are: yellowish -brownish grey, yellowish grey, pale grey 
and dark grey (plate- 1). The texture is mainly vesicular and aphanitic texture (fine grain in which the crystals cannot be detected by naked eye) in addition to few amount of amygdaloidal texture (Plate- 1).

\subsection{Petrography}

The twenty-one thin sections of the studied stone tools' samples were examined by polarized microscope, the petrographic study shows that there are three main lithological groups of these samples and each group represents special mineralogical and textural characteristics. The following is a petrographic description for each group:

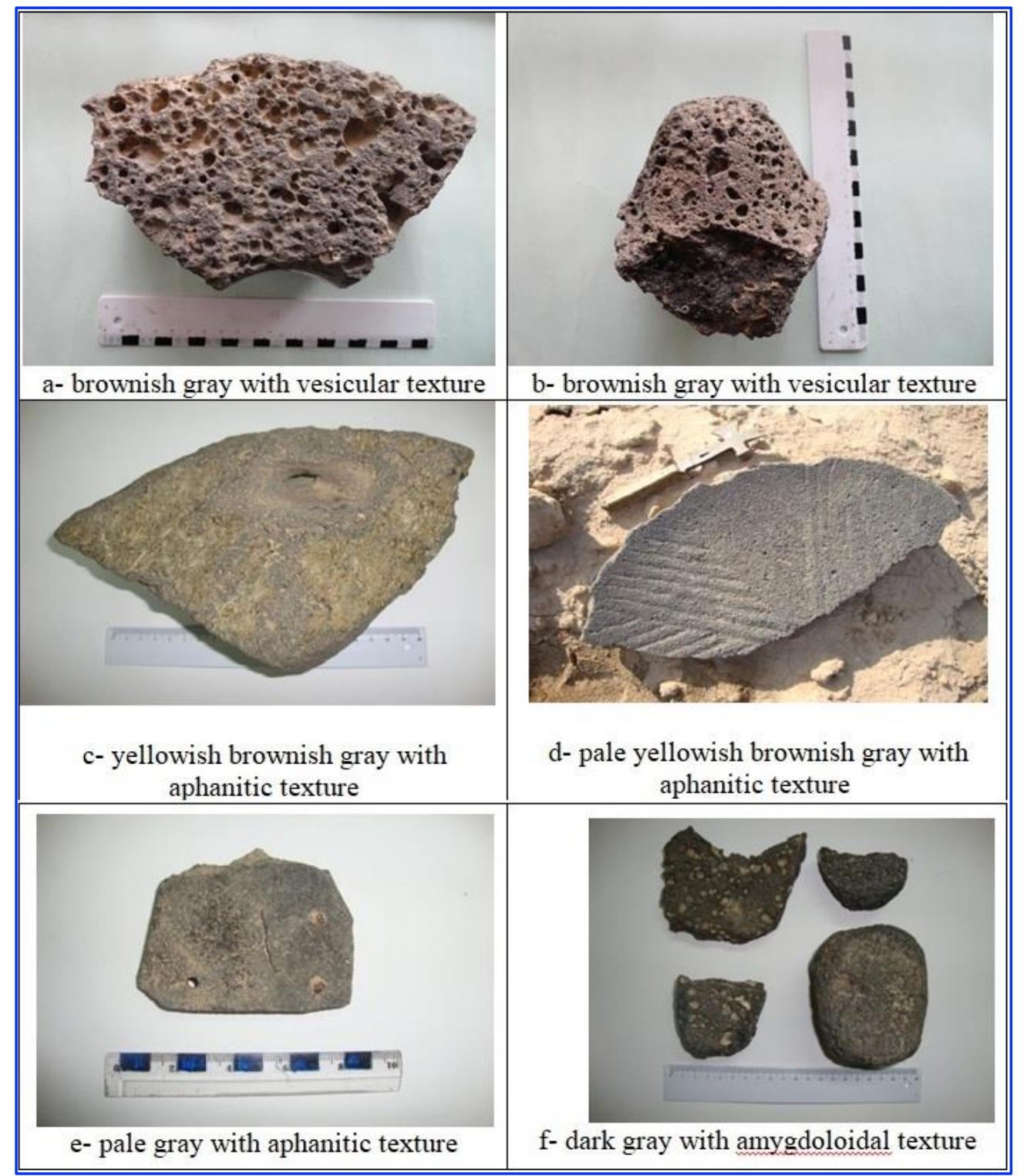

Plate 1. Hand specimen description of basalt stone tools

\subsubsection{Group A}

Vesicular Basalt, contains large voids with diameters ranges between $(0.05-1.5) \mathrm{mm}$, the groundmass is composed of volcanic glass and contains very fine crystals of plagioclase feldspar, olivine, and pyroxene (Plate 2). 


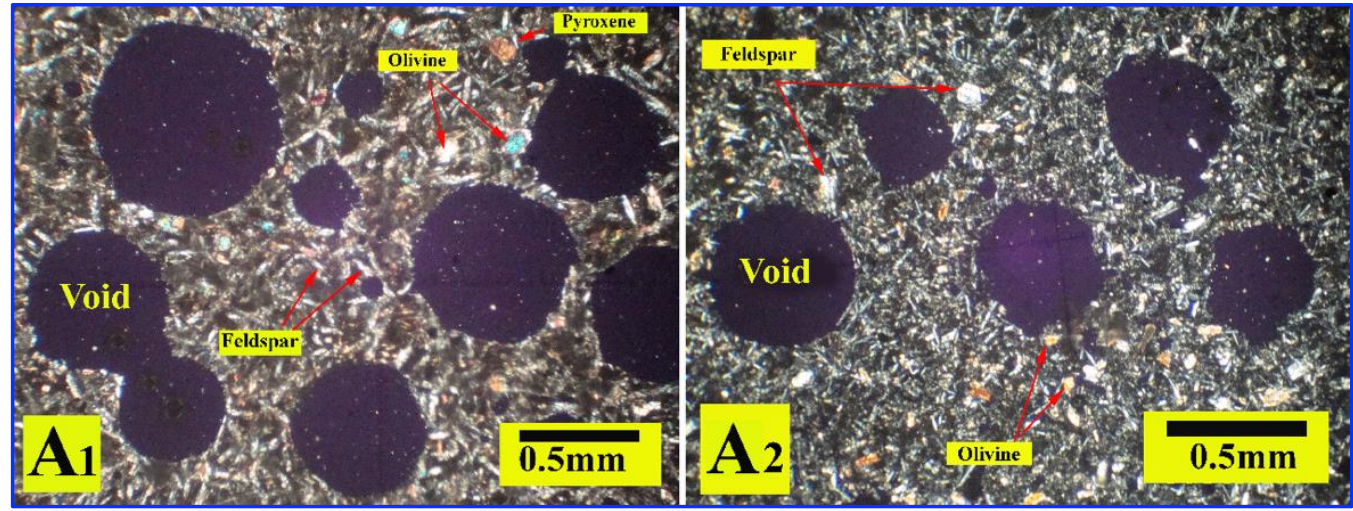

Plate 2. Group A: vesicular basalt with large voids

\subsubsection{Group B}

Olivine Dolerite, contains coarse phenocryst of olivine and feldspar and various sizes of voids, the diameter of these voids ranges between $(0.05-3) \mathrm{mm}$. These rocks contain the same composition of basalt, but the difference is in texture, and they occur as hypabyssal rocks. Olivine crystals are subhedral and altered (oxidized), therefore, the olivine is called Idengsite, the crystals of plagioclase are euhedral to subhedral (Plate 3).

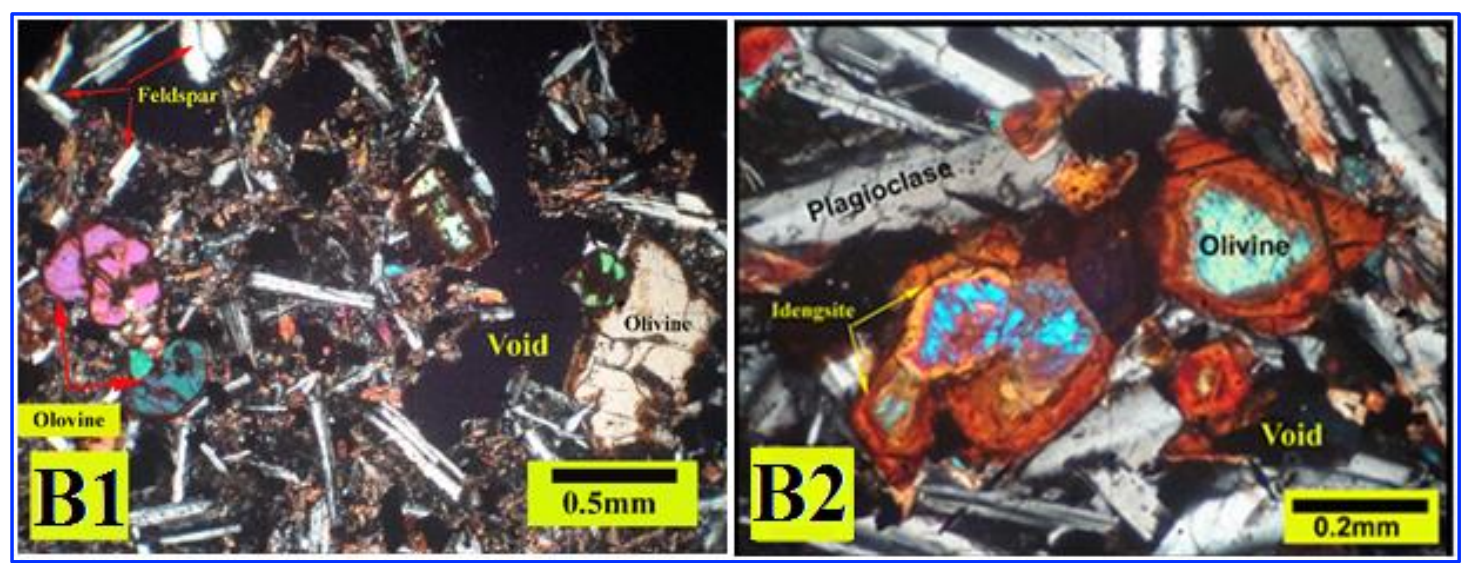

Plate 3. Group B: olivine dolerite contains coarse phenocryst of olivine, feldspar, and various sizes of voids

\subsubsection{Group C}

Olivine basalt, contains various sizes of voids, the diameter of these voids ranges between 0.05 $2.5 \mathrm{~mm}$, and the texture of this group is porphyry, and vesicular. The types of phenocryst are olivine, pyroxene, plagioclase feldspar in the volcanic glass of groundmass. The olivine crystals are subhedral, and altered (Idengsite), the crystals of the plagioclase are euhedral, whereas the pyroxene crystals are subhedral, (Plate 4).

The petrographic study of the collected basalt indicates that not necessarily the same type of basalt is found in the same sampling location. This is because the basalt samples do not represent the original exposures, since they were transported to the sampled locations and were used in domestic uses. The results of the petrographic studied samples are presented in Table 2. These stone tools usually have a porphyritic texture, as well as the source rocks consist of olivine, pyroxene, and plagioclase. In addition to the known accessory minerals of the basalt as well as glass. 


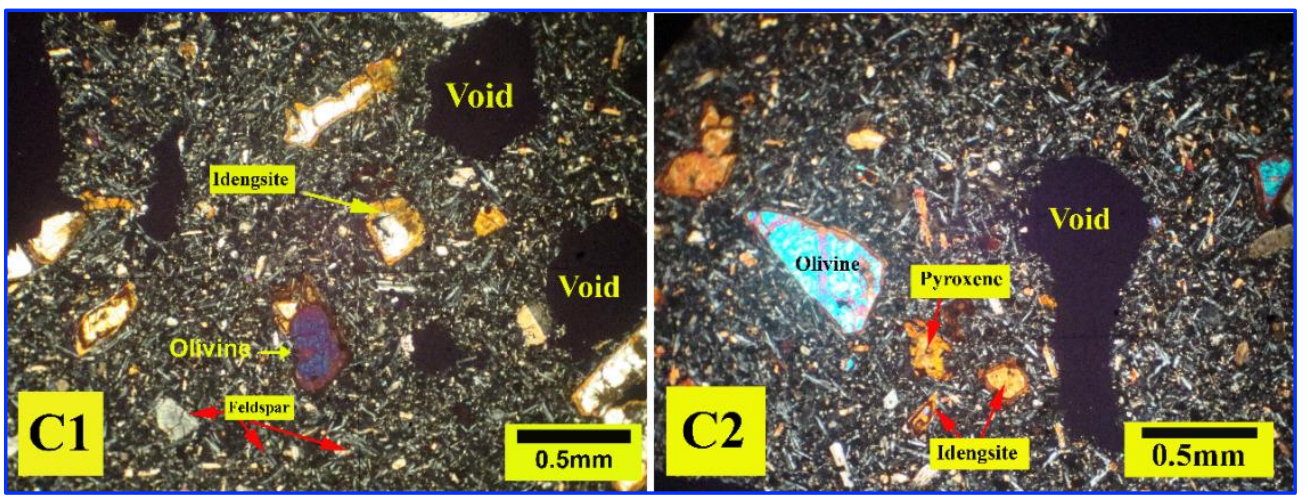

Plate 4. Group C: olivine basalt with various sizes of voids

Table 2. The component, rock type, texture, and lithological group of stone tools of the studied samples

\begin{tabular}{|c|c|c|c|c|c|}
\hline Area & Sample & $\begin{array}{l}\text { Lithological } \\
\text { Group }\end{array}$ & Percentages of Components & Texture & Rock Name \\
\hline \multirow{7}{*}{ 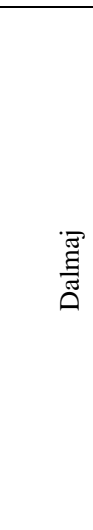 } & D1 & A & $\begin{array}{l}\text { 40\% Glass, } 15 \% \text { Olivine, } \\
\text { 5\% Pyroxene, } 40 \% \text { Feldspar }\end{array}$ & $\begin{array}{l}\text { Vesicular, } \\
\text { Porphery }\end{array}$ & $\begin{array}{l}\text { Vesicular } \\
\text { Basalt }\end{array}$ \\
\hline & D2 & A & $\begin{array}{l}\text { 55\% Glass, } 15 \% \text { Olivine, } \\
\text { 5\%Pyroxene, } 25 \% \text { Feldspar }\end{array}$ & $\begin{array}{l}\text { Vesicular, } \\
\text { Porphery }\end{array}$ & $\begin{array}{l}\text { Vesicular } \\
\text { Basalt }\end{array}$ \\
\hline & D3 & B & $\begin{array}{l}\text { 53\% Feldspar, 30\% Olivine, } \\
\text { 10\% Pyroxene, } 7 \% \text { Magnetite }\end{array}$ & Vesicular & $\begin{array}{l}\text { Olivine } \\
\text { Dolerite }\end{array}$ \\
\hline & D4 & B & $\begin{array}{l}\text { 63\% Feldspar, 25\% Olivine, } \\
\text { 10\% Pyroxene, 2\% Magnetite }\end{array}$ & Vesicular & $\begin{array}{l}\text { Olivine } \\
\text { Dolerite }\end{array}$ \\
\hline & D5 & A & $\begin{array}{l}\text { 87\% Glass, 5\%Olivine, } \\
\text { 3\% Pyroxene, 5\% Feldspar }\end{array}$ & $\begin{array}{l}\text { Vesicular, } \\
\text { Porphery }\end{array}$ & $\begin{array}{l}\text { Vesicular } \\
\text { Basalt }\end{array}$ \\
\hline & D6 & A & $\begin{array}{l}\text { 55\% Glass, } 15 \% \text { Olivine, } \\
\text { 5\%Pyroxene, } 25 \% \text { Feldspar }\end{array}$ & $\begin{array}{l}\text { Vesicular, } \\
\text { Porphery }\end{array}$ & $\begin{array}{l}\text { Vesicular } \\
\text { Basalt }\end{array}$ \\
\hline & D7 & A & 90\% Glass, 5\%Olivine, $5 \%$ Feldspar & $\begin{array}{l}\text { Vesicular, } \\
\text { Porphery }\end{array}$ & $\begin{array}{l}\text { Vesicular } \\
\text { Basalt }\end{array}$ \\
\hline \multirow{5}{*}{$\begin{array}{l}\text { שै } \\
\text { שु }\end{array}$} & G1 & B & $\begin{array}{l}\text { 61\% Feldspar, 30\% Olivine, } \\
5 \% \text { Pyroxene, } 4 \% \text { Magnetite }\end{array}$ & Vesicular & $\begin{array}{l}\text { Olivine } \\
\text { Dolerite }\end{array}$ \\
\hline & G2 & B & $\begin{array}{l}60 \% \text { Feldspar, 30\% Olivine, } \\
7 \% \text { Pyroxene, 3\% Magnetite }\end{array}$ & Vesicular & $\begin{array}{l}\text { Olivine } \\
\text { Dolerite }\end{array}$ \\
\hline & G3 & B & $\begin{array}{l}\text { 67\% Feldspar, } 25 \% \text { Olivine, } \\
\text { 8\% Pyroxene }\end{array}$ & Vesicular & $\begin{array}{l}\text { Olivine } \\
\text { Dolerite }\end{array}$ \\
\hline & G4 & B & $\begin{array}{l}65 \% \text { Feldspar, } 25 \% \text { Olivine, } \\
5 \% \text { Pyroxene, } 5 \% \text { magnetite }\end{array}$ & Vesicular & $\begin{array}{l}\text { Olivine } \\
\text { Dolerite }\end{array}$ \\
\hline & G5 & $\mathrm{C}$ & $\begin{array}{l}\text { 15\% Olivine, } 10 \% \text { Pyroxene, } \\
30 \% \text { Feldspar, } 42 \% \text { Glass , 3\% Magnetite }\end{array}$ & $\begin{array}{l}\text { Vesicular, } \\
\text { Porphery }\end{array}$ & Olivine Basalt \\
\hline \multirow{7}{*}{ 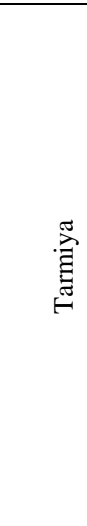 } & $\mathrm{T} 1$ & B & $\begin{array}{l}\text { 65\% Feldspar, } 25 \% \text { Olivine, } \\
5 \% \text { Pyroxene, } 5 \% \text { Magnetite }\end{array}$ & Vesicular & $\begin{array}{l}\text { Olivine } \\
\text { Dolerite }\end{array}$ \\
\hline & $\mathrm{T} 2$ & A & 50\% Glass, $35 \%$ Feldspar, $15 \%$ Olivine & $\begin{array}{l}\text { Vesicular, } \\
\text { Porphery }\end{array}$ & $\begin{array}{l}\text { Vesicular } \\
\text { Basalt }\end{array}$ \\
\hline & $\mathrm{T} 3$ & A & $85 \%$ Glass, $10 \%$ Feldspar, $5 \%$ Olivine & $\begin{array}{l}\text { Vesicular, } \\
\text { Porphery }\end{array}$ & $\begin{array}{l}\text { Vesicular } \\
\text { Basalt }\end{array}$ \\
\hline & $\mathrm{T} 4$ & A & $\begin{array}{l}50 \% \text { Glass, } 10 \% \text { Olivine, } \\
\text { 35\% Feldspar, 5\% Pyroxene }\end{array}$ & $\begin{array}{l}\text { Vesicular, } \\
\text { Porphery }\end{array}$ & $\begin{array}{l}\text { Vesicular } \\
\text { Basalt }\end{array}$ \\
\hline & T5 & A & $\begin{array}{l}50 \% \text { Glass, } 10 \% \text { Olivine, } \\
\text { 37\% Feldspar, } 3 \% \text { magnetite }\end{array}$ & $\begin{array}{l}\text { Vesicular, } \\
\text { Porphery }\end{array}$ & $\begin{array}{l}\text { Vesicular } \\
\text { Basalt }\end{array}$ \\
\hline & T6 & A & $\begin{array}{l}\text { 55\% Glass, } 10 \% \text { Olivine, } \\
30 \% \text { Feldspar, } 5 \% \text { Pyroxene }\end{array}$ & $\begin{array}{l}\text { Vesicular, } \\
\text { Porphery }\end{array}$ & $\begin{array}{l}\text { Vesicular } \\
\text { Basalt }\end{array}$ \\
\hline & $\mathrm{T} 7$ & A & 70\% Glass, $5 \%$ Olivine, $25 \%$ Feldspar & $\begin{array}{l}\text { Vesicular, } \\
\text { Porphery }\end{array}$ & $\begin{array}{l}\text { Vesicular } \\
\text { Basalt }\end{array}$ \\
\hline \multirow{2}{*}{ 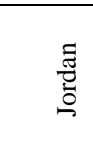 } & $\mathrm{J} 1$ & $\mathrm{C}$ & $\begin{array}{c}\text { 20\% Olivine, 5\% Pyroxene, 35\% Glass, 31\% } \\
\text { Feldspar, 9\% Magnetite }\end{array}$ & $\begin{array}{l}\text { Vesicular, } \\
\text { Porphery }\end{array}$ & Olivine Basalt \\
\hline & $\mathrm{J} 2$ & $\mathrm{C}$ & $\begin{array}{c}15 \% \text { Olivine, } 3 \% \text { Pyroxene, } 35 \% \text { Glass, } \\
\text { 35\% Feldspar, } 12 \% \text { Magnetite }\end{array}$ & $\begin{array}{l}\text { Vesicular, } \\
\text { Porphery }\end{array}$ & Olivine Basalt \\
\hline
\end{tabular}


The comparison between the stone tools and basalt which are exposed in NE Iraq, NE Syria, NE Jordan, NE and central Iran, and NE Turkey showed that the stone tools are similar to some of these basalts. Such as the samples of Group A, vesicular basalt is similar to the Syrian basalt (Turkmani and Al-Shar'a., 2008), and those of Group B, olivine dolerite are petrographically similar to the Northeastern basalt of Iran and Azerbaijan (Amel et al. 2008), and those of Group C, olivine basalt is similar to the Basalt of Jordan within Harat Al-Sham (Ibrahim, 1993).

\subsection{Chemical Composition}

Chemical analyses of the studied samples (Table 3) and according to the relationship of Le Maitre et al. (1989), the Total Alkali $\left(\mathrm{Na}_{2} \mathrm{O}+\mathrm{K}_{2} \mathrm{O}\right) \%$ versus Silica $\left(\mathrm{SiO}_{2}\right) \%$ content (TAS) classification system of igneous rocks, of the current study, showed that the G2 is Foidite, T2, T7 are trachy basalt and D2 is basalt (Fig. 2) in addition to low silica $\left(\mathrm{SiO}_{2}\right)$ between 40.18 to 49.85 wt. \% (Table- 3) of mafic (basic) igneous rocks which may refer to basaltic source materials (Fig. 2).

Table 3. The chemical composition of the samples from Ga'ara Depression, Tarmiya and Dalmaj archaeological sites by XRF analysis

\begin{tabular}{lcccc}
\hline Oxides\% & \multicolumn{3}{c}{ Sample No. } & $\mathrm{T} 7$ \\
\hline & $\mathrm{G} 2$ & $\mathrm{~T} 2$ & $\mathrm{~T} 2$ \\
$\mathrm{SiO}_{2}$ & 40.180 & 49.72 & 47.88 & 49.85 \\
$\mathrm{Al}_{2} \mathrm{O}_{3}$ & 13.41 & 10.21 & 9.79 & 12.38 \\
$\mathrm{TiO}_{2}$ & 2.42 & 0.94 & 0.92 & 1.13 \\
$\mathrm{Fe}_{2} \mathrm{O}_{3}$ & 13.30 & 6.85 & 6.87 & 7.67 \\
$\mathrm{MnO}$ & 0.18 & 0.13 & 0.13 & 014 \\
$\mathrm{CaO}$ & 13.34 & 18.12 & 17.37 & 19.44 \\
$\mathrm{MgO}$ & 4.11 & 4.24 & 4.22 & 3.99 \\
$\mathrm{Na} 2$ & 2.74 & 3.26 & 2.90 & 0.87 \\
$\mathrm{~K}_{2} \mathrm{O}$ & 0.93 & 2.14 & 2.35 & 1.66 \\
$\mathrm{P} 2 \mathrm{O} 5$ & 0.82 & 0.71 & 0.73 & 0.70 \\
Loss on Ignition & 10.92 & 6.57 & 9.35 & 2.41 \\
\hline
\end{tabular}

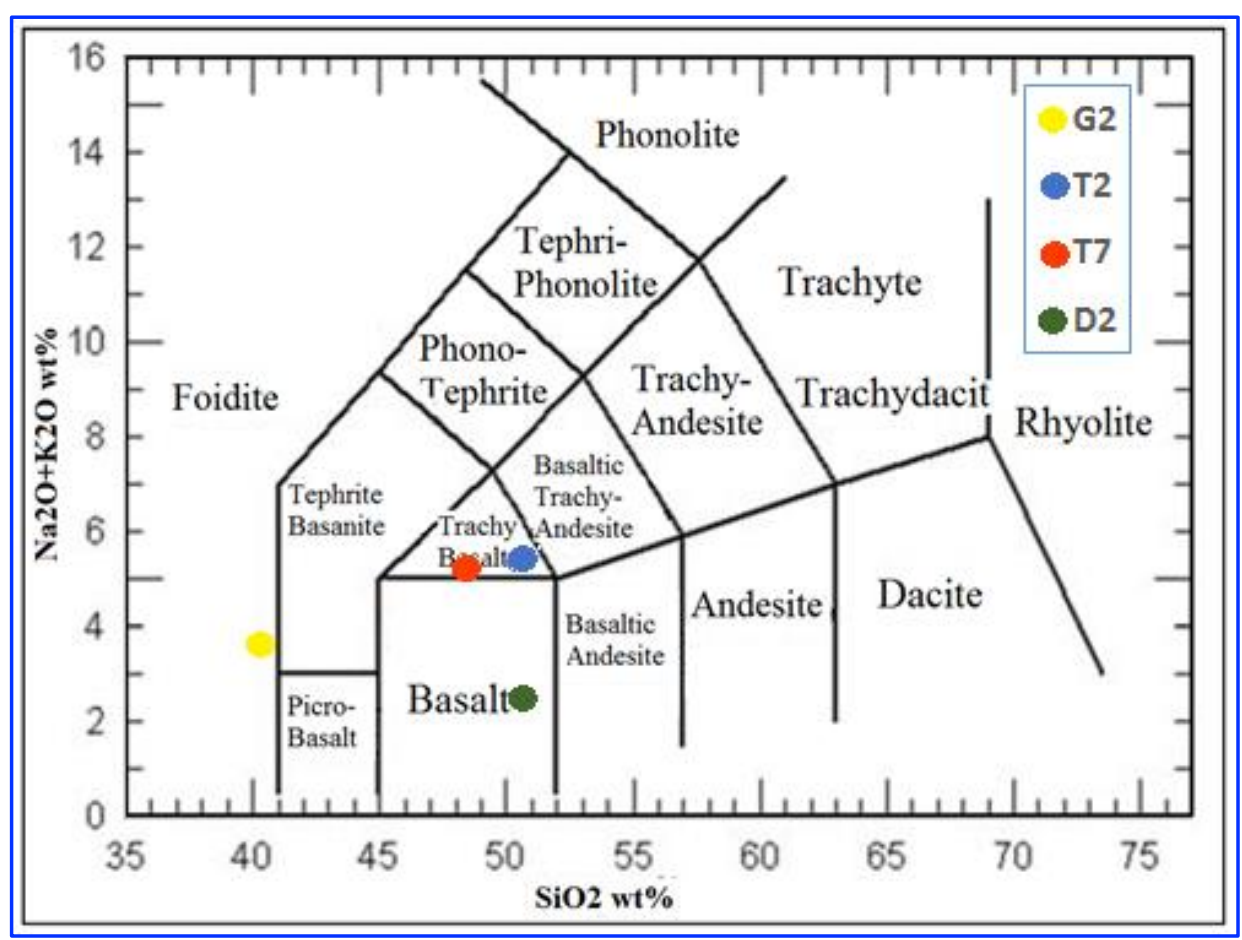

Fig. 2. The relationship between $\mathrm{SiO}_{2}$ and the $\mathrm{Na}_{2} \mathrm{O}+\mathrm{K}_{2} \mathrm{O}$, (Maitre et al. 1989) showed that the main samples have a basaltic and non-basalt origin 


\subsection{Qasar Al-Azraq and multi uses of basalt}

Azraq in Arabic means blue color. Qasar Al-Azraq is located in Azraq Town on the major desert route, about $100 \mathrm{~km}$ east of Amman, Jordan. Field trip by the authors to this site showed multi uses of basalt; such as for building and as stone tools. Ancient builders have used basalt blocks entirely to construct this site as: wall construction (Plate 5a), pillars (Plate 5b), arched partition to create hall (Plate$5 \mathrm{c}$ ), doors, frames and arches (Plate 5d), stairway (Plate 5e) and ceiling roof; by lying stone beams (23 meters length) on cantilevered protruding from the wall (Plate- 5f). The doors were typically designed with hinge, pin, knob, which protruded from the top and bottom edges; so that they could be fitted into socket cups chiseled into the lintel above. Moreover, basalt was used as stone tools such as water container (Plate 6a), mortar (Plate 6b), grinder, scripted stones written by Latin and Arabic (Plate- 6-c), inscription of many type of animals (Plate- 6-d), animals fixer (Plate- 6-e) lining of ground water wells (Plate- 6-e).

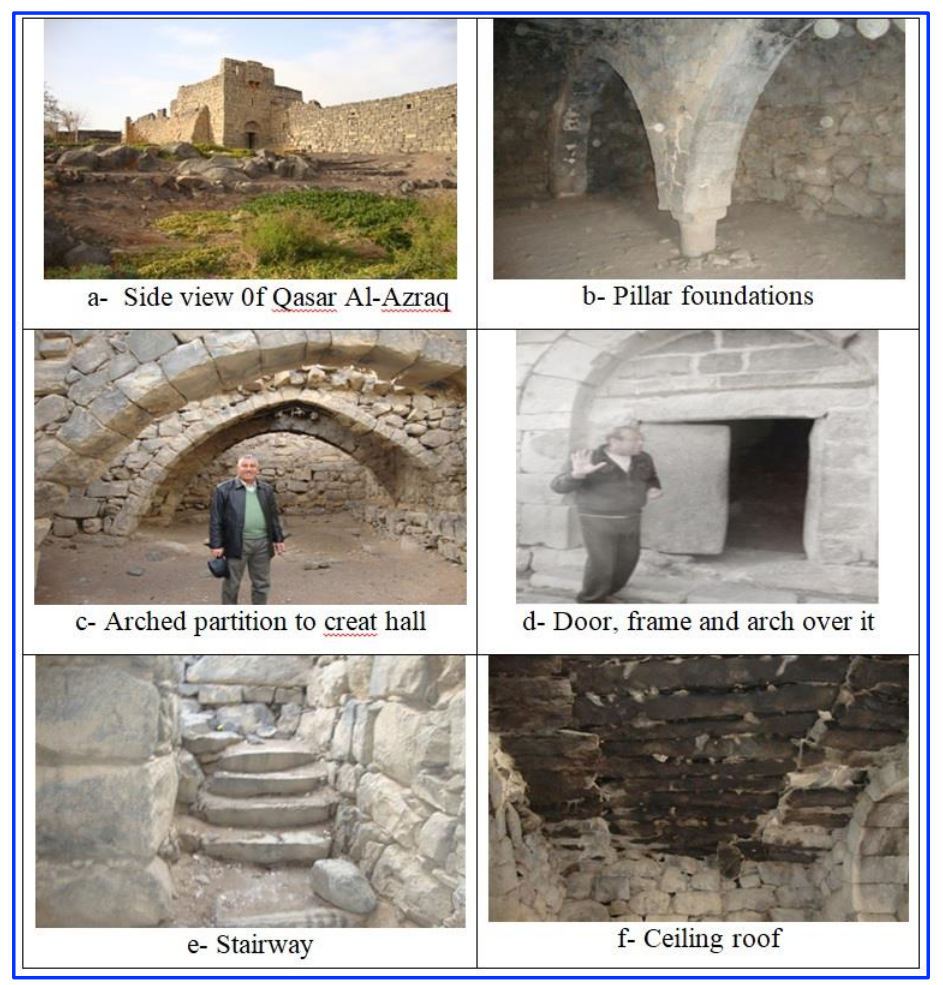

Plate 5. Multi uses of basalt in construct Qasar Al-Azraq, Azraq Town, Jordan

\subsection{Umm Al-Jamal Site}

It is located about $20 \mathrm{~km}$ east of Mafraq, north of Jordan, in the semi- arid region covered by lava flow. This site ranks behind Petra and Jarash sites in size and state of preservation among Jordan's archaeological sites. Literature surveys showed that Umm Al-Jamal site differs from those two sites because it is built entirely of black to gray colored basalt. This site includes many buildings; such as barracks castle, many gates, Nabatian temple, main reservoir, main water channel, many churches, cathedral and tens of houses and housing complexes. Ancient builders in this site have used basalt to construct walls, stairways, arches, doors and ceiling (De Vries, 1979 and 1998); and also, for inscriptions by late Nabatian (De vries, 2007). Physical and mechanical properties of Umm Al-Jamal basalt can be used for constructions purposes because it has high slaked durability, medium strength and high specific gravity (Al-Qadi et al., 2020). This city was constructed by ancient Nabatian during $1^{\text {st }}$ century A. D., and flourished as a frontier city of the Roman and Bezentine Empires and continued to prosper in the Umayyad Period (De vries, 1979). 


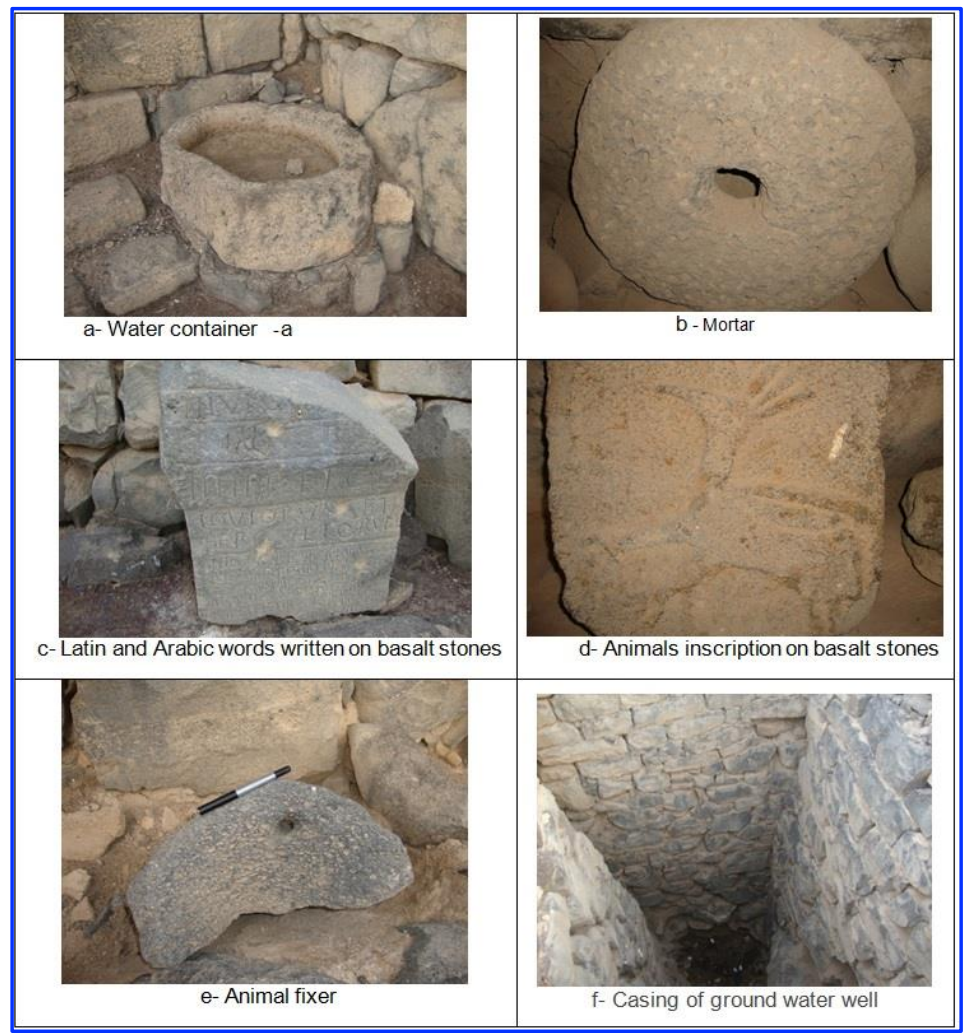

Plate 6. Multi uses of basalt in Qasar Al-Azraq, Azraq Town, Jordan

\section{Discussion}

The occurrences and distributions of basaltic tools in three Iraqi archaeological sites (current study), showed that two of them are within Mesopotamian and the third site is in the Iraqi Western Desert, but there are no basalt exposures close to these sites. The studied stone tools were transported from surrounding exposures of basalt The main important surrounding source areas of basalt are: northeast Iraq, near the Iraqi- Iranian borders (Buday and Jassim, 1987); Harat Al-Sham basalt, which extends from Syria- Jordan- Saudi Arabia (Ibrahim, 1993; Feduik and Al- Fugha, 1999; Abboud, 1999); northeast Syria (Turkmani and Al- Shar'a, 2009); north- east Iran (Tehran et al. 2010) and central Iran (Chatroodi et al. 2010), and north- east Turkey (Yucel et al. 2014a).

The petrographic study showed that the stone tools are composed of three types of basalt: group (A) vesicular basalt, group (B) olivine dolerite, and group (C) olivine basalt. Group (A) is similar to the rock basalt outcrop of north- east Syria. Group (B) is similar to the outcrop of basalt rocks of northeast Iran. Group (C) is similar to the outcrop of northeast Jordan, northeast Iran, and eastern Turkey. Chemical analysis of four samples of stone tools, according to Maitre et al. (1989), showed that three of them are mafic igneous rocks, which refer to basaltic source materials, while the fourth one is nonbasaltic source materials. To discuss the trade routes through which basalt was transported from the exposure of basalt (source areas) to the archaeological sites in which were used as a stone tool. One of the nearby sites is the basalt exposure in north-eastern Iraq. Basalt may be transported from northeast Iraq to the east towards the archaeological sites containing basalt stone tools, such as Karim Shahir, Garmo the oldest agricultural village in the world 9000 BC (Dabbag and Al-Jadir, 1980), Badra Balga, then along the Lesser Zab River, to its intersection with the Tigris River, then towards the south to Tel Al-Sawan and Tarmiyah and then to Dalmaj in Mesopotamia (Map 2). But this type of basalt is soft and not hard enough to be used as stone tools. The basalt found in northeast and middle of Iran and northeast Turkey is relatively far away from the studied archaeological sites, and if the ancients transported them 
to archaeological sites, the cost of transporting them is very high. The exposure of northeast Jordan (Harrat Al-Shaam) is relatively close to Ga'ara area (one of the studied sites), which is located in the Iraqi Western Desert, in which basalt stone tools were found in several sites, and from Ga'ara Depression towards the east, to Euphrates River. This road coincides with the trade routes for the Arab migration and Akadian (Susa, 1990) from the Arabian Peninsula towards the Euphrates River, and then from the Euphrates River towards the southeast along the Euphrates River, in which this route used by Prophet Ibraham during his journey from Ur to Mary and then to Aram (northeast Syria) (Susa, 1990). This route coincides with the road through which the bitumen was transported from Heet to the archaeological site of Tel Al-Oweili (Connan, 1999), which is located south of Ur and Uruk (famous Sumerian cities) south of Mesopotamia. Other basalt rocks exposures are found in northeastern Syria are relatively close to some archaeological sites containing basaltic stone tools such as Tel Satto and Yarm Tappa and from there to the Nineveh (famous archaeological city) on the Tigris River, and then along the river towards the south to the archaeological site Tel Al- Sawan, then to Tarmiyah (current study) to prepare or use it as a stone tools or may be transported to Dalmaj (current study) in Mesopotamia.

Expected trade routes: To expect the trade routes from the exposure (source areas) of basalt rocks to the studied archeological sites, which include stone tools, the following aspects were considered: 1) The results of the petrographic study and geochemical analysis of the collected basalt stone tools, 2) The source area of basalt exposures, 3) Abundance of basalt stone tools at some studied Iraqi archaeological sites, 4) Location of some archaeological sites between source areas and studied sites, 5) The migration of Arabs (4000 BC) and Akkadian from the arid-land of Arabian Peninsula to the Fertile Crescent particularly Mesopotamia (Susa, 1990) 6) Ancient trade routes of bitumen transportation (Connan, 1999), and 7) Migration route of prophet Ibrahim from Ur to the north of Syria (Susa, 1990). Accordingly, some possible trade routes can be estimated, from the source areas (basalt exposures) to the archeological sites, where basalt stone tools were collected. The following three routes are expected:

\subsection{First Route: Harrat Al-Sham, Ga'ara Depression, Euphrates River, Tarmiya, and Dalmaj}

The wide exposures of basalt at Harrat Al-Sham cover an area of about $50000 \mathrm{~km}^{2}$, (Coleman and McGuire, 1988; De Vries, 1998) and it can be cut and shaped easily. These characteristics features promote ancient human to use basalt for building and as stone tools at Umm Al-Jimal and Qasar AlAzraq sites. Arabs were still in motion from Arabian Peninsula towards Mesopotamia such as Akadian migration. This migration has established the oldest and greatest Empire (2371-2230 BC) in the Middle Euphrates near Babylon; and many groups settled at Ana and Rawa towns in the upper Euphrates reach to get necessary required shrubs, water and economic exchange (Susa, 1990). Some of the mentioned migrants returned to homeland to save their relationship with their tribes (Ali, 1980) and the economic and cultural exchanges between Nabatian and ancient habitant of many sites at and near Ga'ara Depression, western Iraq (Al-Zubaidi, 2010). During these migrations, they probably have passed along the Harrat Al-Sham and transported raw materials (basalt) toward Ga'ara Depression sites and then continued eastward to the Euphrates River, following the ancient route of Profit Ibrahim, and finally to the Mesopotamian Plain, particularly Tarmiya and Dalmaj sites (Fig. 3). As well as, they transported the cultures and arts of engraving and shaping basalt to be used as stone tools.

\subsection{Second Route: NE Syria, Tel Satto, Yarim Tappa, Nineveh, Tigris River banks, Tel Al-Sawan, Tarmiya, and Dalmaj}

The basalt exposures at NE Syria (Turkumani and Al- Shara, 2009), and the presence of basalt stone tools at Tel Satto and Yarim Tepee (Al-Ani, 1986), which is located west Mosul city, refer to the most important source of basalt, which was used in above mentioned archaeological sites. These raw materials possibly were transported from NE Syria; as the nearest source and not far away from these 
sites. Then after, transported to Tel Al-Sawan, which contains basalt stone tools (Al-Ani, 1986), through the ancient asphalt route (Connan, 1999). This route was connected between merging point of the Lesser Zab River with the Tigris River at the north, and the Mesopotamian ancient cities such as Uruk, Larsa, Tell El Ouili, and others at the south, passing through Tarmia and Dalmaj sites (Fig. 3).

\subsection{Third Route: Penjwen, Jarmo, Tigris River, Tel Al-Sawan, Tarmiya, and Dalmaj}

Basalt is exposed east of Sulaimaniya city, north east Iraq, near Iraqi- Iranian border (Buday and Jassim, 1987), but it is not hard enough to use it as a stone tools by ancient human (Sissakian, 2020) which is not far away from Jarmo, the first agriculture village on the world (9000 B.C.), (Dabbag and Al-Jadir, 1980) and other archaeological sites such as: Badra Balga, Karim Shahir and Hazar Mird (Map 2). The raw materials were most possibly transported from basalt exposure areas in the east of Sulaymaniya city to the west, to the mentioned archaeological sites. Then, from these sites to the merging point of the Lesser Zab River with the Tigris River, and then after to the ancient bitumen route, which trends southward to Tel Al-Sawan, Al-Tarmiya site, Al- Dalmaj site, and other sites of Mesopotamia Plain (Fig. 3). Therefore, this route is not certain to transport basalt, which is not suitable for use as stone tools because it is not hard enough.

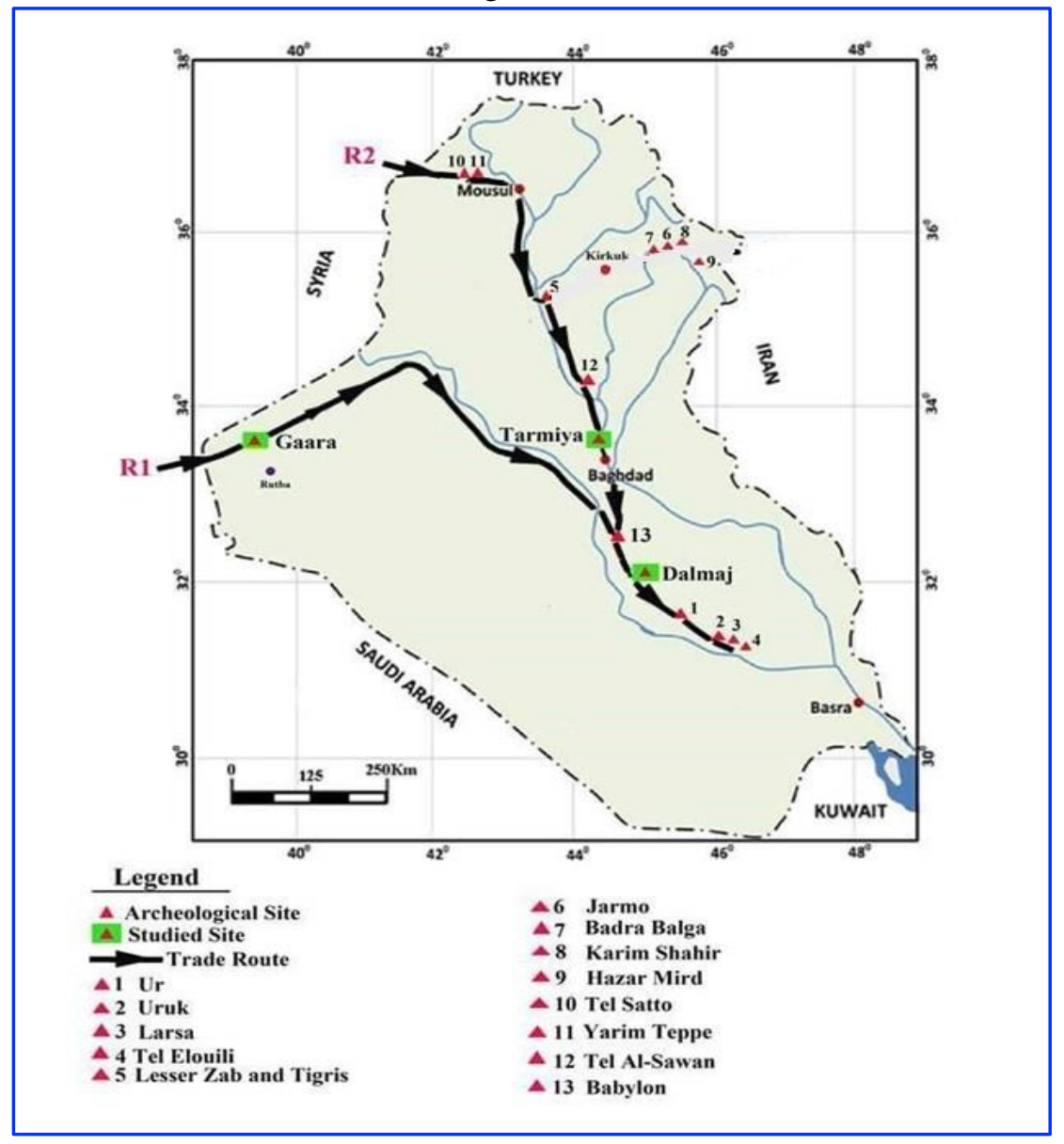

Fig. 3. Expected trade routes of basalt from source areas to the studied archaeological sites

\section{Conclusions}

- Iraq is surrounded by some outcrops of basalt; in Syria, Jordan, Iran, and Turkey and the studied samples of basalt stone tools are similar to some of these basalts. 
- The petrographic study reveals that the stone tools have three groups: Group A: vesicular basalt; Group B: olivine dolorite and Group C: olivine basalt.

- Field survey of Qasar Azraq showed that the basalt rocks were used for building, stone tools, water wells lining and others.

- Chemical composition of the studied stone tools proved that they are composed of foidite, trachy basalt and basalt.

- According to the archaeological evidences, there are two expected trade routes from source areas to the studied archaeological sites: The most important expected trade route is the first one, from basalt source areas of Harrat Al-Sham to the Ga'ara Depression, Euphrates River, Tarmiya and Dalmaj in Mesopotamian. The $2^{\text {nd }}$ trade route from N-E Syria, Tell Satto, Yarim Tepee, Nineveh, Tigris River banks, Tel Al-Sawan, Tarmiya and Dalmaj.

- There were trades, cultural and technical exchanges between Qasar Azraq and Umm Al-Jimal archaeological sites in Jordan and the current studied archaeological sites in Iraq how to use basalt for stone tools, building stones and others.

\section{Acknowledgements}

The authors would like to acknowledge Al-Karkh University of Science for their support in conducting this article. We are also indebted to the Department of Geology, College of Science, University of Baghdad for the supports and slides preparation and to the Natural History Research Center and Museum for the logistic support. Profound thanks to Prof. Dr. M. K. Mohammad from Uruk Private University and Assist. Prof. Dr. Habib M. Shubber from University of Al-Qadisiya for their help in the field surveys. Many thanks to the Munther A. Abdul Malik, from Department of Archaeology, University of Baghdad; and the expert Varoujan K. Sissakian from Department of Natural Resources Engineering \& Management, University of Kurdistan Hewler, KRG, Iraq, for their valuable reviews of the manuscript. The authors are very grateful to the Editor in Chief Prof. Dr. Salih M. Awadh, the Secretary of Journal Mr. Samir R. Hijab. and the Technical Editors for their great efforts and valuable comments.

\section{References}

Abboud, I. A., 1999. Quaternary Paleoenvironment, Paleoclimatic and Paleohydrology of Wadi Muqat Basin, AlBadia, NE Jordan, Unpub. Ph.D. Thesis, College of Science, University of Baghdad, 149p.

Al-Ani, E. T. T., 1986. Stone manufacturing in Iraq till Neolithic end. M.Sc. thesis, College of Arts, University of Baghdad, 226 P. (Arabic).

Al-Baijat, H. M., 2008. The use of basalt aggregates in concrete mixes in Jordan. Jordan Journal of Civil Engineering, 2 (1), 63-70.

Ali, J., 1980, Detailed in the History of the Arabs before Islam, Part 6, 7th edition, Baghdad Al- Nahdha Library. (Arabic).

Al-Qadi, Q., Al-Malabeh, A., Hamed, R., Al-Zawahreh, K., 2020. Engineering performance of selected properties of Umm Al-Jamal basaltic rocks, NE Jordan. Iraqi Geological Journal 53 (1E), 44-54.

Al-Zubaidi, A. A., 2010. The archaeological importance of natural stones near Tell Al-Nasr, Iraqi Western Desert. Al-Adab Journal, 99, 523- 541. (Arabic).

Amel, N., Moayyed, M., Ameri, A., Vosoghi Abedini, M., Moazzen, M., 2008. Petrogenesis of Plio-Quaternary basalts in Azerbaijan, NW Iran and comparisons them with similar basalts in the east of Turkey. Iranian Journal of Crystallography and Mineralogy, 16 (2), 327- 340.

Braidwood, R. J., Howe, B., 1972, Prehistoric Investigation in Iraq Kurdistan.Studies in Ancient Oriental Civilization. No. 13. The University of Chicago Press, 184 p.

Buday, T., Jassim, S. Z., 1987. The Regional Geology of Iraq. V. 2 Tectonism, Magmatism and Metamorphism, GEOSURV, Baghdad, 352 P.

Chatroodi, A. Y., Karizaki, H. S., Ghorbani, M., 2010. Petrology and geochemistry of volcanic rocks in Hozi-eSoltan Area. World Academy of Sciencem Engineering and Technology, 71, 44-48. 
Coleman, R. G., Gregory, R. T. and Brown, G. R., 1983, Cainozoic volcanic rocks of Saudi Arabia. Saudi Arabian Deputy for Mineral Resources, Open- File Report. USGS- OF- 03093, 82 P.

Conan, J., 1999, Use and trade of bitumen in antiquity and prehistory: molecular archaeology reveals secrets of past civilizations. Phil. Trans. R. Soc. Lond. B., 33- 50.

Dabbag, T., Al-Jadir, W., 1980. The Art of Ancient Iraq with an Introductory Chapter on Prehistoric Art. Baghdad. $477 \mathrm{p}$.

De Vries, B., 1979. Research of Umm El- Jimal, Jordan, 1972- 1977. Biblical Archaeologist, 42 (1), 49- 55.

De Vries, B., 1998. Umm El- Jimal, A frontier Town and its landscape in Northern Jordan. Journal of Roman Archaeology, Supplementary series, 20, 91- 122.

Feduik, F., Al- Fugha, H., 1999, Dead Sea region: fault- controlled chemistry of Cenozoic volcanic. Geolines (Praha- Czech), 9, 29- 34.

Ibrahim, K. M., 1993. The Geological framework for the Harrat Al- Sham Basaltic Super- Group and its volcanotectonic evolution. Geology Directorate, Geological Mapping Division. Amman, Jordan, Bull. 25.

Le Maitre R.W., Bateman P., Dudek, A., Keller, J., Lameyre, J., Le Bas, M.J., Sabine, P.A., Schmid, R., Sorensen, H., Streckeisen, A., Woolley, A.R. and Zanettin, B. 1989: A Classification of Igneous Rocks and Glossary of Terms: Recommendations of the International Union of Geological Sciences Subcommission on the Systematics of Igneous Rocks. Blackwell Scientific Publications, Oxford, U.K.

Susa, A 1990, Arab and Juice in History: Historical Evidence Explained by Archaeological Discoveries, 7th edition. Arabic for Printing, Editing and Distribution, 1014 P. (Arabic)

Tehran, M. A., Shahri, H. M., and Valipour, M.E.F., 2010, The Petrographic of Basalt in Northeast of DaroodNeyshapoor, NE Iran. The first International Applied Geological Congress, Islamic Azad University, Mashhad Branch Iran, 26-28 April, 1193-1197.

Turkmani, A., and Al- Shar'a, M., 2009. Petrography and geochemistry of new basaltic rocks in Northeastern Syria. Journal of Damascus university of Pure Science, 25 (1), 97-116.

Yücel, C., Arslan, M., Temizel, I., Abdioğlu, E., 2014. Volcanic facies and mineral chemistry of Tertiary volcanics in the northern part of the Eastern Pontides, northeast Turkey: implications for pre-eruptive crystallization conditions and magma chamber processes. Mineralogy and Petrology, 108 (3), 439-467. 